\title{
To a Question of Ensuring of Competitiveness of
}

\section{Construction Production}

\author{
Ludmila Viktorovna Makarova \\ Department of Quality management and technology of building production, \\ «Penza State University of Architecture and Construction», Penza, Russia
}

\section{Roman Viktorovich Tarasov}

Department of Quality management and technology of building production, «Penza State University of Architecture and Construction», Penza, Russia

Copyright (C) 2014 Ludmila Viktorovna Makarova and Roman Viktorovich Tarasov. This is an open access article distributed under the Creative Commons Attribution License, which permits unrestricted use, distribution, and reproduction in any medium, provided the original work is properly cited.

\begin{abstract}
At formation of development strategy of the enterprise of the construction industry it is necessary to pay attention to increase of production competitiveness, as to the main indicator of its economic activity.

In work the qualitative approach to an assessment of production competitiveness of construction appointment based on the comparative analysis of production taking into account the market segmentation is offered.
\end{abstract}

Keywords: competitiveness, market segmentation, production level of quality

\section{Introduction}

The modern construction market is presented by the wide nomenclature of materials and products of various functional purposes. In these conditions the consumer is compelled to choose from wide range of production that which will satisfy as much as possible to his requirements. And often it is necessary to make a choice among the homogeneous production. Adequacy of a choice of the consumer will depend on degree of study of the market and available knowledge in the field of an assessment of production compliance to the established requirements. 
At the same time, development of the market relations is inseparably linked with fight of producers for more favorable conditions of production and goods sale for the purpose of receiving the maximal profit.

Functioning of any enterprise including the enterprises of the construction industry is impossible without accounting of activity of competitors who in turn are links of one chain - economies.

In this regard increase of competitiveness is a strategic problem of any object of the domestic market which decision is possible on the basis of carrying out the deep analysis of competitiveness as economic category and an indicator of economic activity. Need of comparison of competitiveness of subjects of the market defines in turn the relevance of its quantitative assessment. Therefore development of methods of the quantitative measurement of competitiveness is one of conditions of its management of [1...3].

\section{Experimental study}

In work the qualitative approach to an assessment of competitiveness of construction production based on the comparative analysis of production of various producers and considering division of the market into the separate segments differing with opportunities of goods sale of the producer is offered.

It is known that at an assessment of production competitiveness the important part is assigned to such aspect as the maximal satisfaction of buyers needs, and, therefore, to achievement of a high level of quality. The solution of this task demands an assessment of production level of quality taking into account a set of factors. Process of receiving such assessment can be presented in the form of structural model (figure 1,2) [4, 5].

Reliability of the received assessment of production level of quality depends on a large number of factors, such as strategy of development of the enterprise, a sales market, competitors activity, etc. Thus the particular interest is caused by procedure of an assessment of ponderability of production properties that finally renders a decisive influence at an assessment of a level of quality and development of the corresponding recommendations about upgrading of production quality taking into account, as requirements of the consumer, and taking into account possibility of the next competitors.

For the purpose of receiving an objective assessment of production level of quality of construction appointment it is offered to estimate ponderability of production properties taking into account division of the consumer into segments (figure 2).

Such specification at determination of ponderability of properties gives the chance to the producer of production more precisely to reveal consumer wishes and to offer their production taking into account individual needs of buyer that, undoubtedly, does production more competitive. 


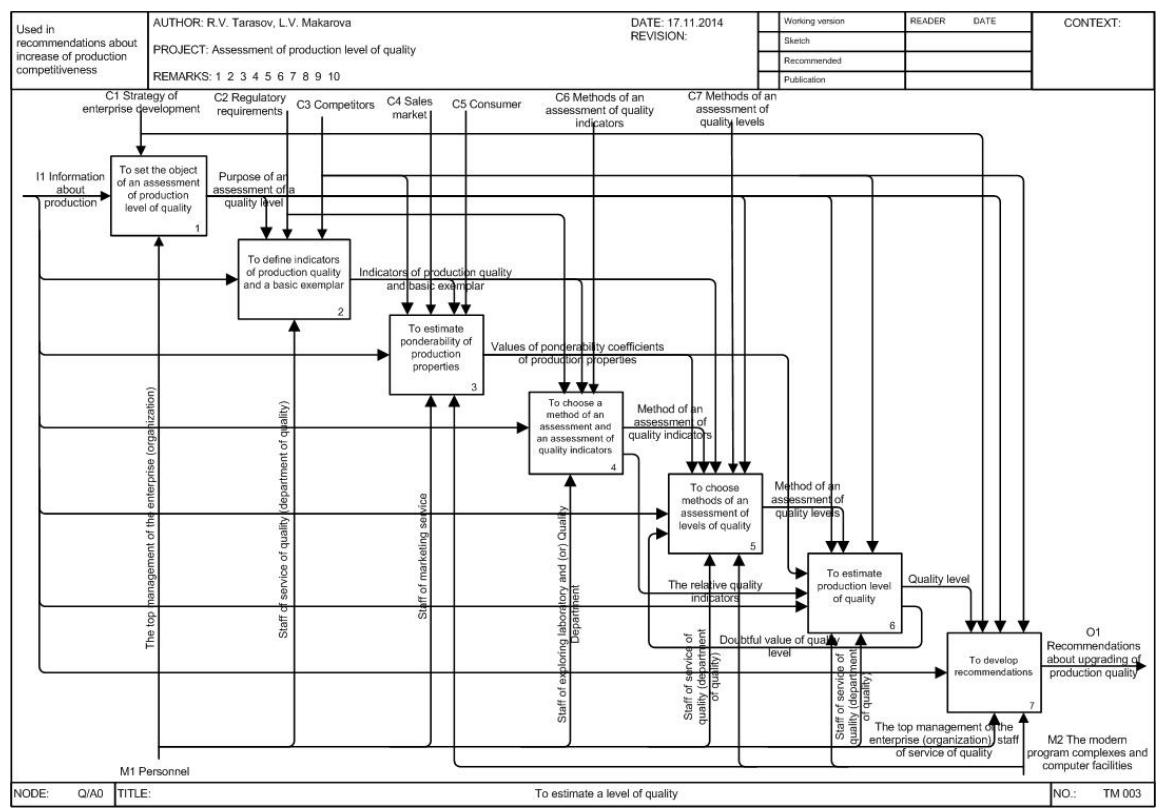

Figure 1: The chart of the top level "To estimate a level of quality"

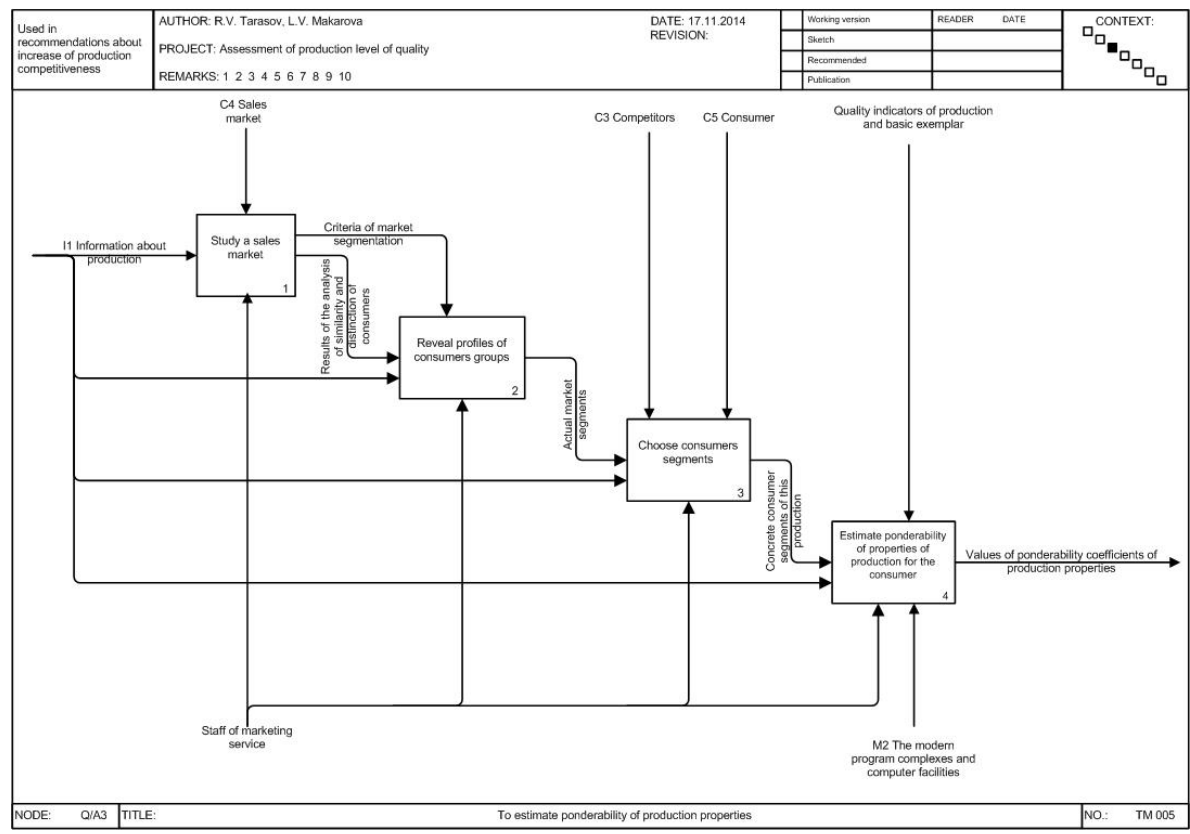

Figure 2: The chart of decomposition "To estimate ponderability of production properties"

We will illustrate the practical value of such qualitative approach on the example of production of construction appointment of various producers.

At a stage of preliminary researches the information about the made coatings based on the comminuted rubber was received. 
For calculation of indicator of production competitiveness the following indicators were used: density, durability at $10 \%$ of deformation, abradability, water absorption, water tightness, frost resistance and the price (table 1).

Table 1: Absolute indicators of production competitiveness

\begin{tabular}{|c|c|c|c|c|c|}
\hline \multirow{2}{*}{$\begin{array}{l}\text { № } \\
\mathrm{a} / \\
\mathrm{a}\end{array}$} & \multirow{2}{*}{$\begin{array}{l}\text { Absolute values of } \\
\text { indicators }\end{array}$} & \multicolumn{4}{|c|}{ Producers } \\
\hline & & $\begin{array}{l}\text { Enterprise } \\
\text { No. } 1 \\
\end{array}$ & $\begin{array}{l}\text { Enterprise } \\
\text { No. } 2 \\
\end{array}$ & $\begin{array}{l}\text { Enterprise } \\
\text { No. } 3\end{array}$ & $\begin{array}{c}\text { Enterprise } \\
\text { No. } 4 \\
\end{array}$ \\
\hline 1 & Density, $\mathrm{kg} / \mathrm{m}^{3}$, not less & 700 & 900 & 800 & $700-1100$ \\
\hline 2 & $\begin{array}{l}\text { Durability at } 10 \% \text { of } \\
\text { deformation, } \mathrm{kg} / \mathrm{cm}^{2} \text {, not } \\
\text { less }\end{array}$ & 6,5 & 6 & 5,5 & 6,5 \\
\hline 3 & $\begin{array}{l}\text { Abradability, } \mathrm{g} / \mathrm{cm}^{2}, \text { no } \\
\text { more }\end{array}$ & 0,05 & 0,05 & 0,04 & 0,05 \\
\hline 4 & $\begin{array}{l}\text { Water absorption, } \%, \text { no } \\
\text { more }\end{array}$ & 8 & 7 & 6 & 8 \\
\hline 5 & $\begin{array}{l}\text { Water tightness, MPa, not } \\
\text { less }\end{array}$ & 0,3 & 0,2 & 0,4 & 0,3 \\
\hline 6 & $\begin{array}{l}\text { Frost resistance, cycles, } \\
\text { not less }\end{array}$ & 200 & 200 & 200 & 200 \\
\hline 7 & Average price, rub. & 1350 & 1400 & 1200 & 1500 \\
\hline
\end{tabular}

For determination of a complex indicator of this production quality, the opinion of two groups of consumers was considered. Values of coefficients of ponderability were received by carrying out of expert poll. Results of the conducted researches are presented in table 2.

Table 2: Values of coefficients of indicators ponderability of production competitiveness

\begin{tabular}{|c|l|c|c|}
\hline \multirow{2}{*}{$\begin{array}{c}\text { № } \\
\text { a/a }\end{array}$} & \multicolumn{1}{|c|}{ Absolute values of indicators } & \multicolumn{2}{|c|}{$\begin{array}{r}\text { Expert assessment of indicators of } \\
\text { consumers groups }\end{array}$} \\
\cline { 3 - 4 } 1 & Density, $\mathrm{kg} / \mathrm{m}^{3}$, not less & 0,1 & 0,07 \\
\hline 2 & $\begin{array}{l}\text { Durability at } 10 \% \text { of deformation, } \\
\mathrm{kg} / \mathrm{cm}^{2}, \text { not less }\end{array}$ & 0,14 & 0,10 \\
\hline 3 & Abradability, g/cm ${ }^{2}$, no more & 0,20 & 0,18 \\
\hline 4 & Water absorption, \%, no more & 0,15 & 0,04 \\
\hline 5 & Water tightness, MPa, not less & 0,14 & 0,14 \\
\hline 6 & Frost resistance, cycles, not less & 0,12 & 0,22 \\
\hline 7 & Average price, rub. & 0,15 & 0,25 \\
\hline
\end{tabular}




\section{Results and discussion}

The generalized indicator of quality is calculated on a formula [6]:

$$
K_{j}^{(O)}=\sum_{i=1}^{n} M_{i j} K_{i j}
$$

where $j$-consumers groups;

$n$ - quantity of the indicators of quality considered at calculation of a technological level;

$M_{i j}$ - coefficient of ponderability of each $\mathrm{i}$ indicator of quality $\mathrm{j}$ consumers groups;

$K_{i j}$ - relative indicator of production quality calculated on the following formulas:

- if the increase of indicator $P_{j}$ rises TUP (indicators 1, 2, 5 and 6)

$$
K_{i j}=\frac{P_{j}}{P_{j(\max )}}
$$

- if the increase $P_{j}$ leads to decrease of TUP (indicators 3, 4 and 7)

$$
K_{i j}=\frac{P_{j(\min )}}{P_{j}}
$$

Consumer usefulness of a product calculates by the following formula:

$$
\Pi=\frac{K_{j}^{(O)}}{K_{j(\max )}^{(O)}}
$$

Results of calculations are presented in table 3.

Table 3: Summary table

\begin{tabular}{|l|c|c|c|c|}
\hline \multirow{2}{*}{\begin{tabular}{c}
\multirow{2}{*}{$\begin{array}{c}\text { Competitiveness } \\
\text { indicators }\end{array}$} \\
\cline { 2 - 5 }
\end{tabular}} & $\begin{array}{c}\text { Enterprise } \\
\text { No. } 1\end{array}$ & $\begin{array}{c}\text { Enterprise } \\
\text { No.2 }\end{array}$ & $\begin{array}{c}\text { Enterprise } \\
\text { No.3 }\end{array}$ & $\begin{array}{c}\text { Enterprise } \\
\text { No.4 }\end{array}$ \\
\hline \multicolumn{4}{|c|}{ Retail trade } & 0,855 \\
\hline $\begin{array}{l}\text { Complex indicators of } \\
\text { production quality }\end{array}$ & 0,812 & 0,804 & 0,923 & 92,6 \\
\hline $\begin{array}{l}\text { Consumer usefulness of } \\
\text { production, \% }\end{array}$ & 87,9 & 87,1 & 100 & 0,878 \\
\hline & Wholesale trade & 94 \\
\hline $\begin{array}{l}\text { Complex indicators of } \\
\text { production quality }\end{array}$ & 0,842 & 0,814 & 0,934 & 100 \\
\hline $\begin{array}{l}\text { Consumer usefulness of } \\
\text { production, \% }\end{array}$ & 90,1 & 87,1 & & 94 \\
\hline
\end{tabular}


According to the received results, production of "Enterprise No. 3" possesses by the greatest consumer usefulness in two considered segments. The increase of complex indicators of quality for a segment of wholesale trade, in comparison with a segment of retail trade, is bound with redistribution of values of ponderability coefficients towards the greatest accounting of such factor, as the price.

\section{Conclusion}

Thus, the assessment of production competitiveness of the enterprises of the construction industry with use of the offered approach will allow to solve the following important problems: to define the position in the particular market; to develop strategic and tactical actions of effective management; to choose partners for the organization of collateral production; to raise funds in perspective production; to make programs of exit of the enterprise to new sales markets.

\section{References}

[1] A. V. Yudanov Competition: theory and practice. M.: Publishing house: GNOME and D. 2001. 304 p.

[2] V. I. Loganina, L. V. Makarova, R. V. Tarasov Assessment of production competitiveness: educational and methodical grant. Penza: PGUAS. 2007. 40 p.

[3] A. I. Buleev The quantitative coefficient of competitiveness of goods and services. Marketing and market researches in Russia. M.: 1997. P 46 - 50.

[4] D. A. Mark, K. Mc. Gowan Methodology for structural analysis and design SADT. M .: Meta. 1993. 240 p.

[5] L. V. Makarova, R. V. Tarasov, E. V. Medvedkova The process approach when developing quality management system processes at the enterprises of the construction industry. Current research and innovation. March 2014. № 3 [electronic resource]. URL: http://web.snauka.ru/issues/2014/03/32204.

[6] V. I. Loganina, L. V. Makarova, R. V. Tarasov Qualimetry and quality managemental. Penza: PGUAS. 2014. 304 p.

Received: November 17, 2014; Published: December 29, 2014 